\title{
MSTMP, a Stilbene Derivative, Protects SH-SY5Y Cells Against Oxidative Stress
}

\author{
Wei-Guo Liu, Jun-Yi Zhao, Hao Zhang, Xin-Yong Liu, Xiu-Li Guo
}

\begin{abstract}
Objective: The protective effects of a novel stilbene derivative, (E)-2-(3,4,5- trimethoxystyryl)-3,5,6-trimethylpyrazine (MSTMP), on hydrogen peroxide $\left(\mathrm{H}_{2} \mathrm{O}_{2}\right.$ )-induced human derived neuroblastoma cell (SH-SY5Y) damage and its molecular mechanisms were investigated. Methods: SH-SY5Y cells were exposed to $200 \mu \mathrm{mol} \mathrm{L}^{-1} \mathrm{H}_{2} \mathrm{O}_{2}$ for $12 \mathrm{~h}$. The effect of MSTMP on cell viability and apoptosis was assessed by 3-(4,5-dimethyl- thiazol-2-yl)-2,5-diphenyl tetrazolium bromide (MTT) assay and flow cytometry method. The activities of lactate dehydrogenase (LDH), superoxide dismutase (SOD) and nitric oxide synthetase (NOS) and the content of malondialdehyde (MDA), reduced glutathione (GSH) and nitric oxide (NO) in cells were determined by commercial kits. The expressions of pro-apoptotic factor caspase-3, caspase-9 and inducible NOS (iNOS) were detected by Western blotting. Intracellular formation of reactive oxygen species (ROS) was assessed using 6-carboxy-2',7'-dichlorofluorescin diacetate (DCFH-DA) fluorescent probe. Results: MSTMP increased the SH-SY5Y cell viability by inhibition of cell apoptosis induced by $\mathrm{H}_{2} \mathrm{O}_{2}$. These effects were accompanied by an increase of SOD activity, GSH level, and a decrease of MDA content. Moreover, MSTMP showed stronger effects on inhibition of LDH leakage, apoptotic cells, intracellular ROS level and the expression of caspase-3 and caspase-9 than TMP. Furthermore, MSTMP induced a decrease of NO level and the activity of iNOS, tNOS in a time-dependent manner. Conclusions: MSTMP prevents $\mathrm{H}_{2} \mathrm{O}_{2}$-induced cell injury through anti-oxidation and anti-apoptosis via ROS-NO pathway.
\end{abstract}

RÉSUMÉ: La MSTMP, un dérivé de stilbène, protège les cellules SH-SY5Y contre le stress oxydatif. Objectif : Nous avons étudié les effets protecteurs d'un nouveau dérivé de stilbène, la (E)-2-(3,4,5-triméthoxystyryl)-3,5,6-triméthylpyrazine (MSTMP), sur le dommage causé à des cellules dérivées de neuroblastome humain ( $\mathrm{SH}-\mathrm{SY} 5 \mathrm{Y})$ par le peroxyde d'hydrogène $\left(\mathrm{H}_{2} \mathrm{O}_{2}\right)$ ainsi que les mécanismes moléculaires en cause. Méthode : Des cellules SH-SY5Y ont été exposées à $200 \mu \mathrm{mol} / \mathrm{L}^{-1} \mathrm{H}_{2} \mathrm{O}_{2}$ pendant 12 heures. L'effet de la MSTMP sur la viabilité des cellules et sur l'apoptose a été évalué au moyen du test au bromure de 3-(4,5-diméthyl-thiazol-2-yl)-2,5-diphényl tétrazolium (MTT) et de la cytométrie en flux. L'activité de la lactate déshydrogénase (LDH), de la superoxyde dismutase (SOD) et de la nitric oxyde synthétase (NOS) et le contenu des cellules en malondialdéhyde (MDA), en glutathion réduit (GSH) et en oxyde nitrique (NO) a été déterminé au moyen d'une trousse commerciale. L'expression des facteurs pro-apoptotiques caspase-3, caspase-9 et NOS inductible (iNOS) a été détecté par buvardage western. La formation intracellulaire de dérivés actifs de l'oxygène (ROS) a été évaluée par une sonde fluorescente au 6-carboxy-2',7'-dichlorofluorescéine diacétate (DCFH-DA). Résultats : La MSTMP augmentait la viabilité des cellules SH-SY5Y en inhibant l'apoptose cellulaire induite par $\mathrm{H}_{2} \mathrm{O}_{2}$. Ces effets étaient accompagnés d'une augmentation de l'activité SOD, du niveau de GSH et une diminution du contenu en MDA. De plus, la MSTMP avait un effet plus marqué sur l'inhibition de la fuite de LDH, les cellules apoptotiques, le niveau intracellulaire de ROS et l'expression de la caspase-3 et de la caspase-9 que la TMP. Par ailleurs, la MSTMP induisait une diminution du niveau de NO et de l'activité de iNOS et de tNOS en fonction du temps. Conclusions : La MSTMP prévient le dommage cellulaire induit par $\mathrm{H}_{2} \mathrm{O}_{2}$ en agissant comme agent antioxydant et antiapoptotique via la voie ROS-NO.

Can J Neurol Sci. 2014; 41: 382-388

\section{INTRODUCTION}

Oxidative stress on neuronal cells, characterized by an imbalance in the cellular activity related to the production and elimination of reactive oxygen species (ROS), is involved in the pathophysiology of neurodegenerative diseases, such as Alzheimer's disease (AD), vascular dementia (VD) and cerebral ischemia ${ }^{1}$. In AD patients, who are highly sensitivity to ROS, accumulated intracellular oxygen free radicals induce membrane lipid peroxidation, DNA structure damage, and even damage of the fluidity and permeability of cell membranes ${ }^{2,3}$. Reactive oxygen species can also induce apoptosis by triggering numerous signaling transduction pathways, including members of the mitogen-activated protein kinase (MAPK) family, p53 transcription factors and caspase- 3 activation ${ }^{4}$. Therefore, anti-oxidants and anti-apoptotic agents are promising candidates for chemopreventive agents for treating neurodegenerative diseases ${ }^{5}$.

Tetramethylpyrazine (TMP), is a major component in the traditional Chinese herb Chuanxiong (Ligusticum wallichii Franchat), which is used in China as a calcium antagonist and an antioxidant for the treatment of cardiovascular diseases and

From the Department of Pharmacology (WGL, JYZ, HZ, XYL, XLG), Key Laboratory of Chemical Biology (Ministry of Education), School of Pharmaceutical Sciences, Shandong University; Department of Pharmacy (WGL), Qianfoshan Hospital, Jinan;

The Affiliated Hospital of Shandong Medical College (JYZ), Linyi, P.R. China. Received September 9, 2013. Final Revisions Submitted November 8, 2013. Correspondence to: Xiu-Li Guo, No. 44 Wen Hua Xi Road, Department of Pharmacology, School of Pharmaceutical Sciences, Shandong University, Jinan, 250012, P.R. China. Email: guoxl@sdu.edu.cn . 
myocardial and cerebral ischemic diseases because of its effectiveness and low toxicity ${ }^{6,7}$. However, pharmacokinetic studies have shown that TMP presents low bioavailability and is metabolized quickly in vivo with a short half-life of 2.89 hours (h) ${ }^{8}$. Furthermore, accumulating toxicity was shown in patients when TMP is administrated frequently in order to maintain effective plasma concentrations ${ }^{9}$. Therefore, it is necessary to develop new generations of cerebral-cardio-vascular medicines via the molecular modification of TMP. Tetramethylpyrazine stilbene derivatives were produced by replacing the methyl group of TMP molecule with the pharmacophore of resveratrol (RES) (-styryl) by hybridization and bioisosteric replacement. Resveratrol has been shown to benefit several human disease models, including neuro- and cardio-protection, immune regulation and cancer chemoprevention. Apoptotic and antioxidant mechanisms are the main targets of RES for its broad spectrum of actions ${ }^{10-12}$. We designed and synthesized these analogues in order to improve the pharmacodynamic and pharmacokinetic properties of TMP and RES. Our previous study showed that the TMP stilbene derivative CSTMP exhibited stronger anti-oxidation and anti-apoptosis effects on human endothelial cells than TMP and RES ${ }^{13}$. We further screened the protective effects of these TMP analogues against oxidative stress in nerve cells. Results showed that (E)-2-(3,4,5trimethoxystyryl)-3,5,6-trimethyl-pyrazine (MSTMP) showed more potential protection.

In the present study, we used human derived neuroblastoma cells (SH-SY5Y) to investigate the neuroprotective effect of

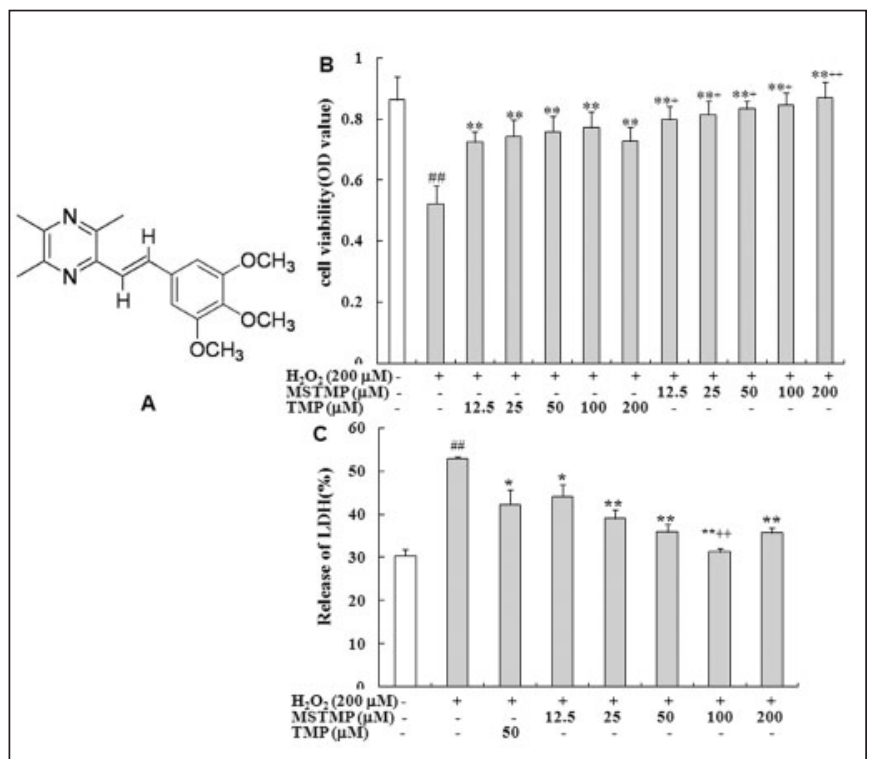

Figure 1: Protective effect of MSTMP on SH-SY5Y cells in response to $\mathrm{H}_{2} \mathrm{O}_{2}$. A: Chemical structure of MSTMP. B: MTT assay. Cells were incubated with MSTMP or TMP for $30 \mathrm{~min}$ and then exposed to $\mathrm{H}_{2} \mathrm{O}_{2}$ $\left(200 \mu \mathrm{mol} \cdot \mathrm{L}^{-1}\right)$ for $12 \mathrm{~h}$ before the cell viability was determined by MTT assay. $C$. Release of $L D H(\%)=L D H$ activities in supernatant $/(L D H$ activities in supernatant and lysate of cells). All data were expressed as mean \pm S.D. $(n=8) .{ }^{\#} P<0.01$ vs. unstimulated cells; ${ }^{*} P<0.05,{ }^{* * *} P<0.01$ vs. $\mathrm{H}_{2} \mathrm{O}_{2}$-stimulated cells; ${ }^{+} \mathrm{P}<0.05,{ }^{++} \mathrm{P}<0.01 \mathrm{vs}$. cells treated with $\mathrm{H}_{2} \mathrm{O}_{2}+T M P$ at the same concentration of MSTMP.
MSTMP (Figure 1A), against oxidation injury induced by hydrogen peroxide $\left(\mathrm{H}_{2} \mathrm{O}_{2}\right)$ and the underlying mechanism.

\section{Materials AND Methods}

\subsection{Materials}

The stilbene derivative MSTMP was synthesized by the Institute of Medical Chemistry of Shandong University. Dulbecco's modified Eagle's medium (DMEM) were purchased from GIBCO BRL (Grand Island, NY, USA). 3-(4,5-dimethylthiazol-2-yl)-2,5-diphenyl tetrazolium bromide (MTT), Dimethyl sulfoxide (DMSO), 6-carboxy-2',7'- dichlorofluorescin diacetate (DCFH-DA), Annexin V fluorescein isothiocyanate (Annexin VFITC) and propidium iodide (PI) were purchased from Sigma (St. Louis, MO, USA). Thirty percent $(30 \%) \mathrm{H}_{2} \mathrm{O}_{2}$ solution was obtained from Wako (Osaka, Japan). Antibodies against caspase3 , caspase-9, $\beta$-actin, and inducible nitric oxide synthetase (iNOS) were purchased from Cell Signaling Technology (Boston, MA, USA). Biotinylated goat anti-rabbit immunoglobin $\mathrm{G}$ ( $\mathrm{IgG}$ ) and nitrocellulose membranes were purchased from Amersham (Buckinghamshire, UK). The LumiGLO Reserve Chemiluminescent Substrate Kit was purchased from KPL (Gaithersburg, MD, USA). The lactate dehydrogenase (LDH), superoxide dismutase (SOD), reduced glutathione (GSH), malondialdehyde (MDA), total nitric oxide synthetase (tNOS), iNOS and nitric oxide (NO) detection kits were purchased from the Nanjing Jiancheng Bioengineering Institute (Nanjing, PR China). All other chemicals used were of analytical grade and obtained from Shanghai Sangon Biological Engineering Technology \& Sciences Co. Ltd. (Shanghai, China).

\subsection{Cell culture and treatment}

Human derived neuroblastoma cells (SH-SY5Y) were cultured in DMEM supplemented with $10 \%$ (v/v) heatinactivated fetal bovine serum, $100 \mathrm{U} / \mathrm{ml}$ penicillin and 100 $\mu \mathrm{g} / \mathrm{ml}$ streptomycin in a humidified atmosphere of $5 \% \mathrm{CO}_{2} / 95 \%$ air at $37^{\circ} \mathrm{C}$.

For all experiments, cells were used at passages 3 to 6 and seeded at a concentration of $4 \times 10^{4}$ cells $/ \mathrm{ml}$ on 96 -well plates and $7.5 \times 10^{4}$ cells $/ \mathrm{ml}$ on 6 -well plates. MSTMP or TMP was freshly prepared as stock solution in DMSO, and diluted with DMEM supplement $(0.1 \%(\mathrm{v} / \mathrm{v})$ DMSO). DMSO was present at equal concentrations $(0.03 \%)$ in all groups. The $\mathrm{H}_{2} \mathrm{O}_{2}$ was freshly prepared before each experiment. Cells were pretreated with MSTMP or TMP at $12.5 \sim 200 \mu \mathrm{mol} \mathrm{L}^{-1}$ for 30 minutes (min), then exposed to $\mathrm{H}_{2} \mathrm{O}_{2}\left(200 \mu \mathrm{mol} \cdot \mathrm{L}^{-1}\right)$ for $6 \mathrm{~h}$ or $12 \mathrm{~h}$.

\subsection{Measurement of cell viability by MTT assay}

Cell viability was measured by MTT assay. Briefly, cells were seeded at a concentration of $4 \times 10^{4}$ cells $/ \mathrm{ml}$ in $96-$-well plates. After pretreated with MSTMP or TMP at 12.5 200 $\mu \mathrm{mol} \cdot \mathrm{L}^{-1}$ for $30 \mathrm{~min}$ before exposure to $\mathrm{H}_{2} \mathrm{O}_{2}$ for $12 \mathrm{~h}, 20 \mu \mathrm{l}$ MTT solution was added to each well at a final concentration of 0.5 $\mathrm{mg} \cdot \mathrm{ml}^{-1}$. After $4 \mathrm{~h}$ incubation, $200 \mu \mathrm{l}$ DMSO was added to each well, and then the optical density was read with a microtiter plate reader (Spectra Rainbow, Tecan, Austria) at a wavelength of 570 $\mathrm{nm}$. Cells pretreated $0.03 \%$ DMSO solution for $30 \mathrm{~min}$ before exposure to $\mathrm{H}_{2} \mathrm{O}_{2}$ for $12 \mathrm{~h}$ was used as a negative control. 


\subsection{Detection of cellular LDH release}

SH-SY5Y cells were pretreated with MSTMP or TMP at 12.5 200 $\mu \mathrm{mol}: \mathrm{L}^{-1}$ for $30 \mathrm{~min}$, and then stimulated with $\mathrm{H}_{2} \mathrm{O}_{2}$ $\left(200 \mu \mathrm{moll}^{-1}\right)$ for $12 \mathrm{~h}$. Cellular $\mathrm{LDH}$ release into the culture supernatants was measured using a commercially available kit according to the manufacture's protocol. To determine the intracellular LDH activity, cells were lysed with lysis buffer (150 mmol: $\mathrm{L}^{-1} \mathrm{NaC} 1,150 \mathrm{mmol} \cdot \mathrm{L}^{-1}$ Tris-HCl, 1 mmol: $\mathrm{L}^{-1}$ EDTA, $1 \%$ Triton $\mathrm{X}-100)$. The supernatants were obtained by centrifugation at $13,000 \mathrm{rpm}(12100 \times \mathrm{g})$ at $4^{\circ} \mathrm{C}$ for $15 \mathrm{~min} . \mathrm{LDH}$ release $(\%)=$ (LDH activity in supernatants) / (LDH activity in supernatants + LDH activity in total cells) $\times 100 \%{ }^{14}$.

\subsection{Detection of intracellular MDA and NO content and enzymes activity}

SH-SY5Y cells were pretreated with MSTMP at 12.5, 25, 50, $100 \mu \mathrm{mol} \mathrm{L}^{-1}$ or $50 \mu \mathrm{mol} \mathrm{L}^{-1} \mathrm{TMP}$ for $30 \mathrm{~min}$, and then stimulated with $\mathrm{H}_{2} \mathrm{O}_{2}\left(200 \mu \mathrm{mol} \mathrm{L}^{-1}\right)$ for $12 \mathrm{~h}$. The cells were washed twice ice-cold PBS and lysed with extraction buffer (20 mmol: $\mathrm{L}^{-1}$ Tris- $\mathrm{HCl}, \mathrm{pH} 7.5,150 \mathrm{mmol} \mathrm{L}^{-1} \mathrm{NaCl}, 1 \mathrm{mmol} \cdot \mathrm{L}^{-1}$ EDTA, 1 mmol: $\mathrm{L}^{-1}$ EGTA, $1 \%$ Triton X-100, $2.5 \mathrm{mmol}^{-1}$ sodium pyrophosphate, $1 \mathrm{mmol} \cdot \mathrm{L}^{-1} \beta$-glycerophosphate, 1 $\mathrm{mmol} \cdot \mathrm{L}^{-1} \mathrm{Na}_{3} \mathrm{VO}_{4}, 1 \mu \mathrm{g} \cdot \mathrm{ml}^{-1}$ leupeptin, and $\left.1 \mathrm{mmol} \cdot \mathrm{L}^{-1} \mathrm{PMSF}\right)$. Protein concentrations of cell extracts were determined by the bicinchonininc acid (BCA) assay (Hyclone-Pierce, South Logan, USA). Cell lysates were collected and used for determination of the MDA, GSH and NO contents and enzymatic activities, including SOD, tNOS and iNOS using commercial kits.

\subsection{Measurement of cellular ROS}

Intracellular formation of ROS was assessed as described previously using the oxidation sensitive dye DCFH-DA as the substrate ${ }^{15}$. Briefly, SH-SY5Y cells were treated with MSTMP at $25,50,100 \mu \mathrm{mol} \cdot \mathrm{L}^{-1}$, or $50 \mu \mathrm{mol} \cdot \mathrm{L}^{-1}$ Tetramethylpyrazine for 30 min, and then stimulated with $\mathrm{H}_{2} \mathrm{O}_{2}\left(200 \mu \mathrm{mol} \cdot \mathrm{L}^{-1}\right)$ for $12 \mathrm{~h}$. After washing with PBS, $20 \mu \mathrm{mol} \cdot \mathrm{L}^{-1}$ DCFH-DA was introduced in dark for $30 \mathrm{~min}$ at $37^{\circ} \mathrm{C}$. Then cells were washed with PBS twice to remove extracellular DCFH-DA. The formation of $2^{\prime}, 7^{\prime}$-dichlorofluorescin (DCF) due to oxidation of DCFH in the presence of various ROS was measured with a VICTOR Wallac 1420 Multilabel Counter (Perkin Elmer Life Science, USA) $(E x=485 \mathrm{~nm}, \mathrm{Em}=538 \mathrm{~nm})$.

\subsection{Determination of cell apoptosis by Flow cytometry}

Early apoptosis and late apoptosis/necrosis of SH-SY5Y cells induced by $\mathrm{H}_{2} \mathrm{O}_{2}$ were detected quantitatively by flow cytometric analysis using AnnexinV and $\mathrm{PI}^{16}$. Cells were harvested by non-enzymatic cell dissociation and centrifugation $\left(120 \times \mathrm{g}, 5 \mathrm{~min}, 4^{\circ} \mathrm{C}\right)$ to remove the medium. The cells were washed three times with binding buffer $\left(10 \mathrm{mmol} \mathrm{L}^{-1}\right.$ Hepes, 140 $\mathrm{mmol} \mathrm{L}^{-1} \mathrm{NaCl}, 2.5 \mathrm{mmol} \cdot \mathrm{L}^{-1} \mathrm{CaCl}_{2}$ ) and stained with $20 \mu \mathrm{g} \mathrm{ml^{-1 }}$ Annexin V-FITC for $30 \mathrm{~min}$ and then incubated with PI (final concentration, $3.7 \mu \mathrm{mol} \mathrm{L}^{-1}$ ) for $10 \mathrm{~min}$. Annexin V and PI emissions were detected in the FL1-H and FL2-H channels of a FACSVantage flow cytometer (Becton Dickinson Immunocytometry System, San Jose, CA, USA), using emission filters of 525 and $575 \mathrm{~nm}$, respectively.
2.8 Measurement of the expression of caspase-3, caspase-9 and iNOS using Western blotting analysis

After treatment with $50 \mu \mathrm{mol} \cdot \mathrm{L}^{-1}$ MSTMP or $50 \mu \mathrm{mol} \mathrm{L}^{-1}$ TMP, confluent monolayers of the SH-SY5Y cells in 6-well plates were washed twice with ice-cold PBS and lysed with extraction buffer. The protein concentrations of the cell extracts were determined by the BCA assay. Total cell lysate was subjected to Sodium dodecyl sulfate (SDS)-polyacrylamide gel electrophoresis (PAGE), transferred to a nitrocellulose membrane, and incubated with monoclonal antibodies against caspase-3, caspase-9 or $\beta$-actin or polyclonal antibody against iNOS. Immunoblots were developed using horseradish peroxidase-conjugated secondary antibodies ${ }^{17}$. Immunoreactive bands were visualized by enhanced chemiluminescent (ECL) system (Amersham Pharmacia Biotech, Piscataway, NJ, USA) and quantified by densitometry using a ChemiDoc XRS (BioRad, Berkeley, Califonia, USA). The density of each band was normalized by $\beta$-actin for their respective lanes.

\subsection{Statistical analysis}

The results are expressed as means \pm S.D. of three independent experiments. Statistical comparisons were performed by analysis of variance (ANOVA) followed by Tukey's test. A probability value $<0.05$ was considered significant.

\section{RESULTS}

3.1 MSTMP increases SH-SY5Y cells survival in cell response to $\mathrm{H}_{2} \mathrm{O}_{2}$

MSTMP has no significant effect on normal SH-SY5Y cells (data not shown). The exposure of SH-SY5Y cells to $\mathrm{H}_{2} \mathrm{O}_{2}$ at $200 \mu \mathrm{mol} \mathrm{L}^{-1}$ for $12 \mathrm{~h}$ resulted in significant reduction of cell viability. Treatment of the cells with MSTMP for $12 \mathrm{~h}$, however, attenuated the $\mathrm{H}_{2} \mathrm{O}_{2}$ effect on cell viability in a concentrationdependent manner. A similar protective effect of MSTMP was also observed in TMP treated-cells. Moreover, MSTMP showed better protection on SH-SY5Ys viability than TMP at the same concentration (Figure 1B).

Treatment of the cells with $200 \mu \mathrm{mol} \mathrm{L}^{-1} \mathrm{H}_{2} \mathrm{O}_{2}$ for $12 \mathrm{~h}$ significantly increased LDH release from the cells (an indicator of membrane integrity) (Figure 1C). Pretreatment of the cells with various concentration of MSTMP for $30 \mathrm{~min}$ prior to incubation with $\mathrm{H}_{2} \mathrm{O}_{2}$ significantly prevented the cellular LDH release induced by $\mathrm{H}_{2} \mathrm{O}_{2}$ in a MSTMP concentration-dependent manner. Moreover, $50 \mu \mathrm{mol} \mathrm{L}^{-1}$ MSTMP showed better inhibition of LDH release than $50 \mu \mathrm{mol} \mathrm{L}^{-1} \mathrm{TMP}$.

\subsection{MSTMP inhibits apoptosis induced by $\mathrm{H}_{2} \mathrm{O}_{2}$}

The cytoprotective action of MSTMP on apoptosis induced by $\mathrm{H}_{2} \mathrm{O}_{2}$ was evaluated by flow cytometric analysis using the Annexin V-FITC cell surface binding. In this assay, the cell population of Annexin $\mathrm{V}^{-} / \mathrm{PI}^{-}$was normal healthy cells, while the Annexin $\mathrm{V}^{+} / \mathrm{PI}^{-}$cells were early apoptotic cells and Annexin $\mathrm{V}^{+} / \mathrm{PI}^{+}$were necrosis/late apoptotic cells. Typical examples of the assessments are shown in Figure 2A-F. We found that $4.7 \%$ of cells in the control group showed early and late apoptosis. An increase of apoptotic cells was observed in the $\mathrm{H}_{2} \mathrm{O}_{2}$-treated 


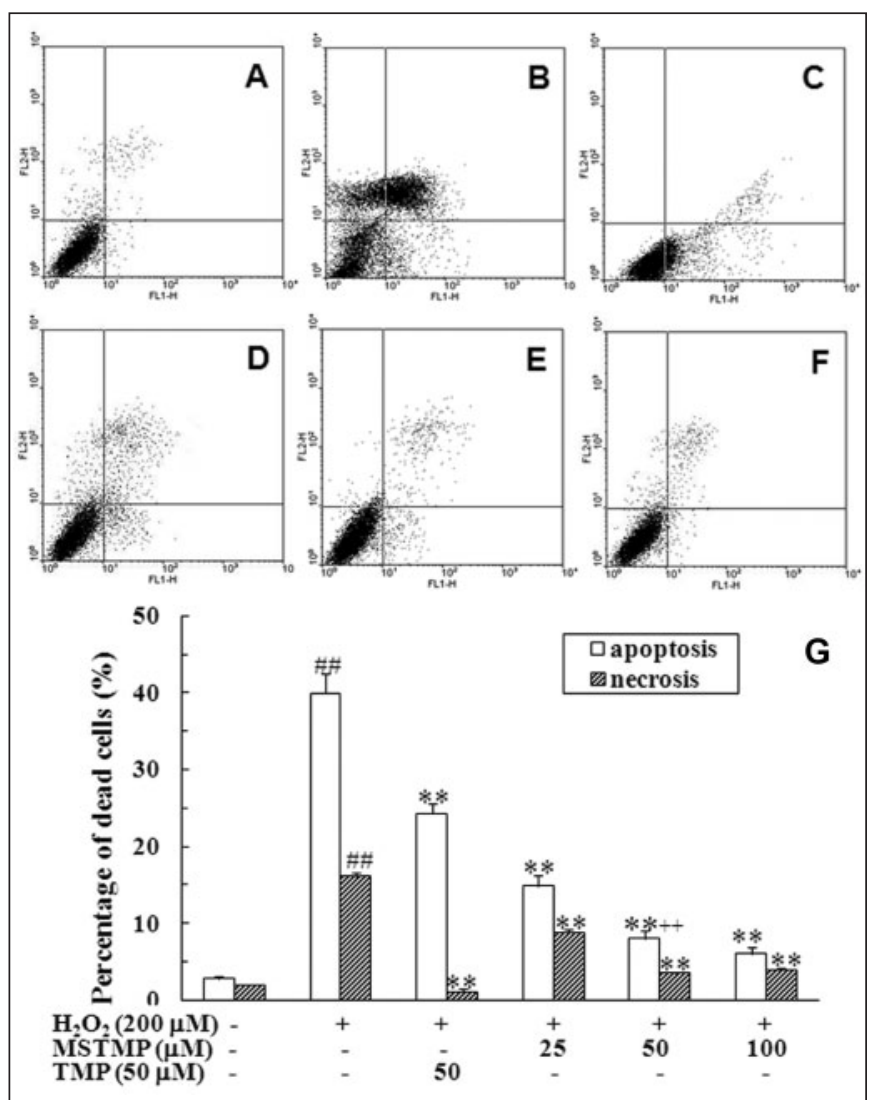

Figure 2: Inhibitory effect of MSTMP on cell apoptosis and necrosis induced by $\mathrm{H}_{2} \mathrm{O}_{2}$. SH-SY5Y cells were incubated in drug-free medium (A) or medium containing $\mathrm{H}_{2} \mathrm{O}_{2}(B)$ for $12 \mathrm{~h}$; or cells were preincubated with $50 \mu \mathrm{mol} \cdot \mathrm{L}^{-1} \mathrm{TMP}(C)$ or $25 \mu \mathrm{mol} \cdot \mathrm{L}^{-1}(D), 50 \mu \mathrm{mol} \cdot \mathrm{L}^{-1}(E)$, and 100 $\mu \mathrm{mol} \cdot \mathrm{L}^{-1}(\mathrm{~F}) \mathrm{MSTMP}$ for $30 \mathrm{~min}$ before $\mathrm{H}_{2} \mathrm{O}_{2}$. Distinction between living, early apoptotic, and late apoptotic/necrotic cells and examples of dotplots were determined by flow cytometry following annexin $V$ and PI double-staining. Horizontal axis represents annexin $V$ intensity and vertical axis shows PI staining. The results shown in $(G)$ are mean $\pm S . D$. for three independent experiments. ${ }^{\#} P<0.01 \mathrm{vs}$. unstimulated cells; ${ }^{* *} \mathrm{P}<0.01$ vs. $\mathrm{H}_{2} \mathrm{O}_{2}$-stimulated cells $;{ }^{++} \mathrm{P}<0.01 \mathrm{vs}$. cells treated with $\mathrm{H}_{2} \mathrm{O}_{2}$ $+T M P$.

group. MSTMP treatment led to a decrease in the rate of early apoptosis and necrosis/late apoptosis in cells exposed to $\mathrm{H}_{2} \mathrm{O}_{2}$. This effect of MSTMP was observed in a dose-dependent manner (Figure 2G).

\subsection{MSTMP inhibits caspase-3, caspase-9 expression in apoptotic $\mathrm{SH}-\mathrm{SY} 5 \mathrm{Y}$ cells induced by $\mathrm{H}_{2} \mathrm{O}_{2}$}

To test whether MSTMP affected the expression of caspase-3 and caspase-9, the apoptosis marker, specific antibodies against caspase- 3 and caspase- 9 were used for Western blotting assay. In cells exposed to $\mathrm{H}_{2} \mathrm{O}_{2}$ for $24 \mathrm{~h}$, expression of caspase- 3 and caspase-9 was significantly enhanced. However, in $\mathrm{H}_{2} \mathrm{O}_{2}$ exposed cells treated with MSTMP at concentrations of 50 $\mu \mathrm{mol} \cdot \mathrm{L}^{-1}$ and $50 \mu \mathrm{mol} \cdot \mathrm{L}^{-1} \mathrm{TMP}$, the increased expression of caspase-3 and caspase-9 was inhibited (Figure 3). These results demonstrate that MSTMP could prevent oxidant-induced apoptosis through inhibition of caspase-3 and caspase-9 activation.

\subsection{MSTMP decreases lipid peroxidation and increases free radical scavenging}

Incubation of SH-SY5Y cells with $200 \mu \mathrm{mol} \mathrm{L}^{-1} \mathrm{H}_{2} \mathrm{O}_{2}$ for $12 \mathrm{~h}$ caused a significant increase of MDA content and a marked decrease of SOD activity and GSH levels (Table). The presence of MSTMP significantly attenuated the increased MDA content, the decrease of SOD activity and GSH level induced by $\mathrm{H}_{2} \mathrm{O}_{2}$ in a MSTMP concentration-dependent manner. In comparison to treatment with $\mathrm{H}_{2} \mathrm{O}_{2}$, treatment of the cells with MSTMP reduced the MDA content by $34.9 \%$ (at $25 \mu \mathrm{mol} \mathrm{L}^{-1}$ ), $39.4 \%$ (at $50 \mu \mathrm{mol} \cdot \mathrm{L}^{-1}$ ) and $42.3 \%$ (at $100 \mu \mathrm{mol} \cdot \mathrm{L}^{-1}$ ), respectively. The activities of SOD were increased by $47.5 \%\left(25 \mu \mathrm{mol} \cdot \mathrm{L}^{-1}\right), 65.3 \%$ $\left(50 \mu \mathrm{mol} \cdot \mathrm{L}^{-1}\right)$ and $82.7 \%\left(100 \mu \mathrm{mol} \cdot \mathrm{L}^{-1}\right)$, respectively. The levels of GSH were increased by $23.1 \%\left(25 \mu \mathrm{mol} \mathrm{L}^{-1}\right), 38.5 \%$ (50 $\left.\mu \mathrm{mol} \cdot \mathrm{L}^{-1}\right)$ and $47.4 \%\left(100 \mu \mathrm{mol} \cdot \mathrm{L}^{-1}\right)$ by MSTMP. The similar inhibitive effects on the increase of MDA content and the decrease of GSH level was observed in TMP treated-group. Moreover, $50 \mu \mathrm{mol} \mathrm{L}^{-1}$ MSTMP showed better inhibition of SOD decrease than $50 \mu \mathrm{mol} \cdot \mathrm{L}^{-1} \mathrm{TMP}$.

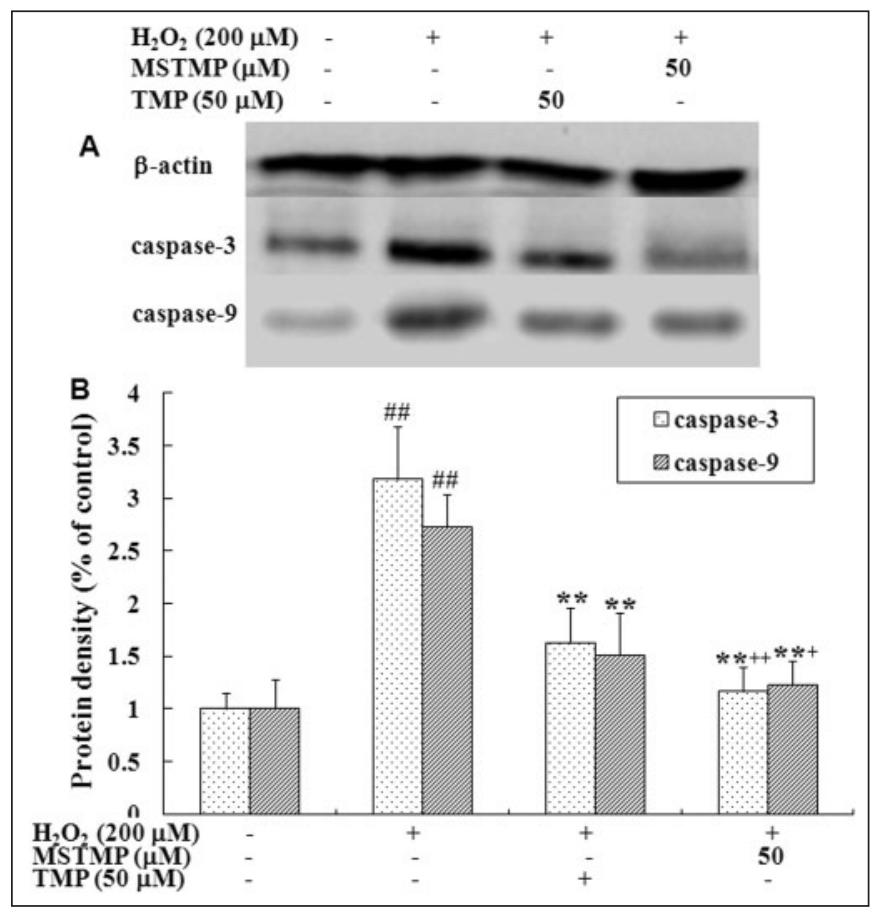

Figure 3: Effect of MSTMP on $\mathrm{H}_{2} \mathrm{O}_{2}$-induced elevation of apoptosis markers caspase-3 and caspase-9. SH-SY5Y cells were pretreated with $50 \mu \mathrm{mol} \cdot \mathrm{L}^{-1}$ MSTMP or TMP for $30 \mathrm{~min}$ and then exposed to $\mathrm{H}_{2} \mathrm{O}_{2}(200$ umol $\mathrm{L}^{-1}$ ) for $12 \mathrm{~h}$. Cells were lysed and the expressions of caspase-3 and caspase-9 were analyzed by Western blotting. Representative blots and quantitative data evaluated by densitometry are shown $(n=3)$. The data are expressed as mean $\pm S D .{ }^{\# \#} P<0.01$ vs. unstimulated cells; ${ }^{* *} P<0.01$ vs. $\mathrm{H}_{2} \mathrm{O}_{2}$-stimulated cells; ${ }^{+} \mathrm{P}<0.05,{ }^{++} \mathrm{P}<0.01 \mathrm{vs}$. cells treated with $\mathrm{H}_{2} \mathrm{O}_{2}+T M P$. 


\begin{tabular}{|c|c|c|c|c|}
\hline Groups & $\begin{array}{c}\text { Dose } \\
(\mu \mathrm{mol} / \mathrm{L})\end{array}$ & MDA (nmol/mgprot) & SOD (U/mgprot) & GSH (ug/mgprot) \\
\hline Normal & - & $60.51 \pm 13.22$ & $907.73 \pm 20.53$ & $1.28 \pm 0.06$ \\
\hline $\mathrm{H}_{2} \mathrm{O}_{2}$ & 200 & $141.95 \pm 22.69^{\# \#}$ & $509.97 \pm 26.14^{\# \#}$ & $0.78 \pm 0.05^{\# \#}$ \\
\hline \multirow[t]{3}{*}{$\mathrm{TMP}+\mathrm{H}_{2} \mathrm{O}_{2}$} & 50 & $96.75 \pm 14.81^{* *}$ & $744.75 \pm 27.76^{* *}$ & $1.10 \pm 0.08^{* *}$ \\
\hline & 12.5 & $108.82 \pm 25.56$ & $564.67 \pm 35.02$ & $0.84 \pm 0.06$ \\
\hline & 25 & $92.34 \pm 19.57^{* *}$ & $752.45 \pm 8.64^{* *}$ & $0.96 \pm 0.07^{* *}$ \\
\hline \multirow[t]{2}{*}{ MSTMP $+\mathrm{H}_{2} \mathrm{O}_{2}$} & 50 & $85.98 \pm 18.78^{* *}$ & $842.83 \pm 32.37^{* *++}$ & $1.08 \pm 0.03^{* *}$ \\
\hline & 100 & $81.89 \pm 11.20^{* *}$ & $931.60 \pm 59.12^{* *}$ & $1.15 \pm 0.04^{* *}$ \\
\hline
\end{tabular}

${ }^{\# \#} P<0.01$, significant difference compared with untreated cells (Normal). ${ }^{* *} P<0.01$, significant difference compared with $\mathrm{H}_{2} \mathrm{O}_{2}$-treated cells. ${ }^{++} \mathrm{P}<0.01$, significant difference compared with cells treated with $\mathrm{H}_{2} \mathrm{O}_{2}+\mathrm{TMP}$, mgprot=mg protein

\subsection{MSTMP inhibits the cellular production of ROS}

The production of ROS in SH-SY5Y cells in response to $\mathrm{H}_{2} \mathrm{O}_{2}$ was examined using the fluorescence probe DCF. We found that $\mathrm{H}_{2} \mathrm{O}_{2}$ treatment resulted in an increase in DCF fluorescence intensity compared with cells treated with cultured medium only (Figure 4). The increase in the DCF signal was suppressed by pretreatment of the cells with 25,50 or 100 $\mu \mathrm{mol} \cdot \mathrm{L}^{-1} \mathrm{MSTMP}$ or $50 \mu \mathrm{mol} \mathrm{L}^{-1} \mathrm{TMP}$. These results indicate that MSTMP effectively inhibited the production of total cellular ROS.

3.6 MSTMP inhibits NO production, iNOS/tNOS activities and iNOS expression in SH-SY5Y cells in response to $\mathrm{H}_{2} \mathrm{O}_{2}$

The NO production in cells was increased and reached its peak at $24 \mathrm{~h}$, then decreased gradually. The presence of MSTMP (at $50 \mu \mathrm{mol} \cdot \mathrm{L}^{-1}$ ) for $6 \mathrm{~h}$ to $48 \mathrm{~h}$ significantly reduced the cellular content of NO (Figure $5 \mathrm{~A}$ ). $\mathrm{H}_{2} \mathrm{O}_{2}$ treatment also increased the cellular activities of iNOS/tNOS. The presence of MSTMP (at 50 $\mu \mathrm{mol} \cdot \mathrm{L}^{-1}$ ) and TMP (at $50 \mu \mathrm{mol} \cdot \mathrm{L}^{-1}$ ) decreased the activity of iNOS and tNOS, the expression of iNOS induced by $\mathrm{H}_{2} \mathrm{O}_{2}$ (Figure 5B, 5C and 5D). Moreover, $50 \mu \mathrm{mol} \mathrm{L}^{-1} \mathrm{MSTMP}$ showed better inhibition of both NO content and iNOS/tNOS activity than TMP.

\section{Discussion}

Reactive oxygen species often caused accelerated aging and chronic diseases, including neurodegenerative diseases and inflammation, by inducing oxidative damage in biomolecules, such as carbohydrates, proteins, lipids, and DNA ${ }^{18}$. Hydrogen peroxide is a well-known ROS that is formed during normal metabolism, where it is produced in the brain during the catalytic degradation of neurotransmitters. Hydrogen peroxide could form highly reactively and deleterious hydroxyl radicals by the Fenton reaction, and partially mediates the toxicity of $A \beta$, the major pathological hallmark for $\mathrm{AD}^{19}$. In the present study, we observed that $\mathrm{H}_{2} \mathrm{O}_{2}$ could markedly destroy the integrity of SH-
SY5Y cell membranes, as demonstrated by LDH release, and lead to massive apoptosis, as evidenced by flow cytometry. Pretreatment of MSTMP on the cells effectively protected SHSY5Y cells from $\mathrm{H}_{2} \mathrm{O}_{2}$-induced damage through an antioxidative action and from apoptosis through inhibition of the ROS-NO pathway.

Tetramethylpyrazine is one of important therapeutic agents for the treatment of some cerebral and cardiovascular diseases, acting as an antioxidant and by other pharmacological actions $^{20,21}$. MSTMP is a novel stilbene derivative via molecular

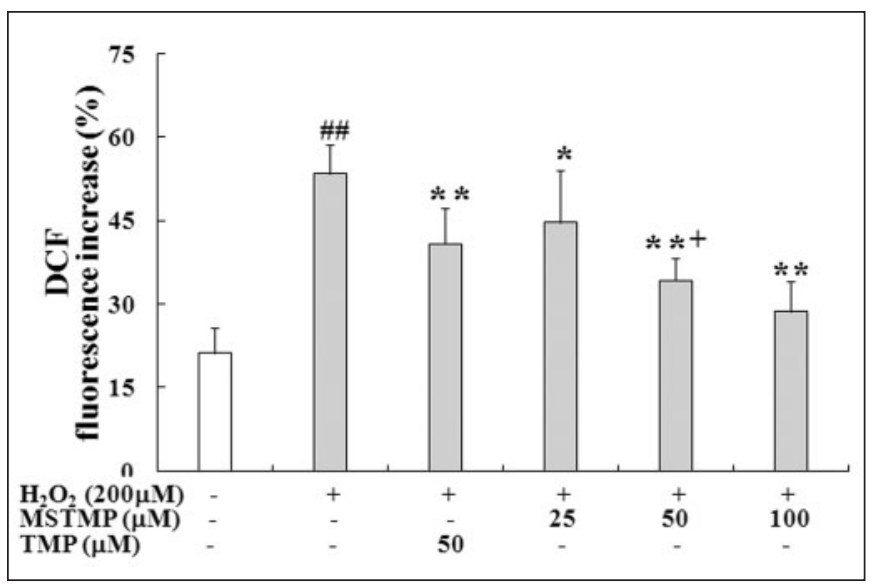

Figure 4: Effect of MSTMP on ROS production in SH-SY5Y cells in response to $\mathrm{H}_{2} \mathrm{O}_{2}$. Cells were labeled with non-toxic fluorescence dye, DCFH-DA, and treated with different concentrations of MSTMP or TMP for $30 \mathrm{~min}$ followed by exposed to $\mathrm{H}_{2} \mathrm{O}_{2}\left(200 \mu \mathrm{mol} \cdot \mathrm{L}^{-1}\right)$ for $12 \mathrm{~h}$. Fluorescence intensities of DCF due to oxidation of DCFH by cellular $\mathrm{ROS}$ (generated by $\mathrm{H}_{2} \mathrm{O}_{2}$ ) were detected $(\mathrm{Ex}=485 \mathrm{~nm}$ and $\mathrm{Em}=535 \mathrm{~nm})$. ROS produced quantified by DCF fluorescence and depicted as percentage of fluorescence increase. All data were expressed as mean \pm S.D. $(n=8)$. ${ }^{\# \#} P<0.01$, vs. unstimulated cells; ${ }^{*} P<0.05,{ }^{* *} P<0.01$ vs. $\mathrm{H}_{2} \mathrm{O}_{2}$-stimulated cells; ${ }^{+} \mathrm{P}<0.05$ vs. cells treated with $\mathrm{H}_{2} \mathrm{O}_{2}+$ TMP. 


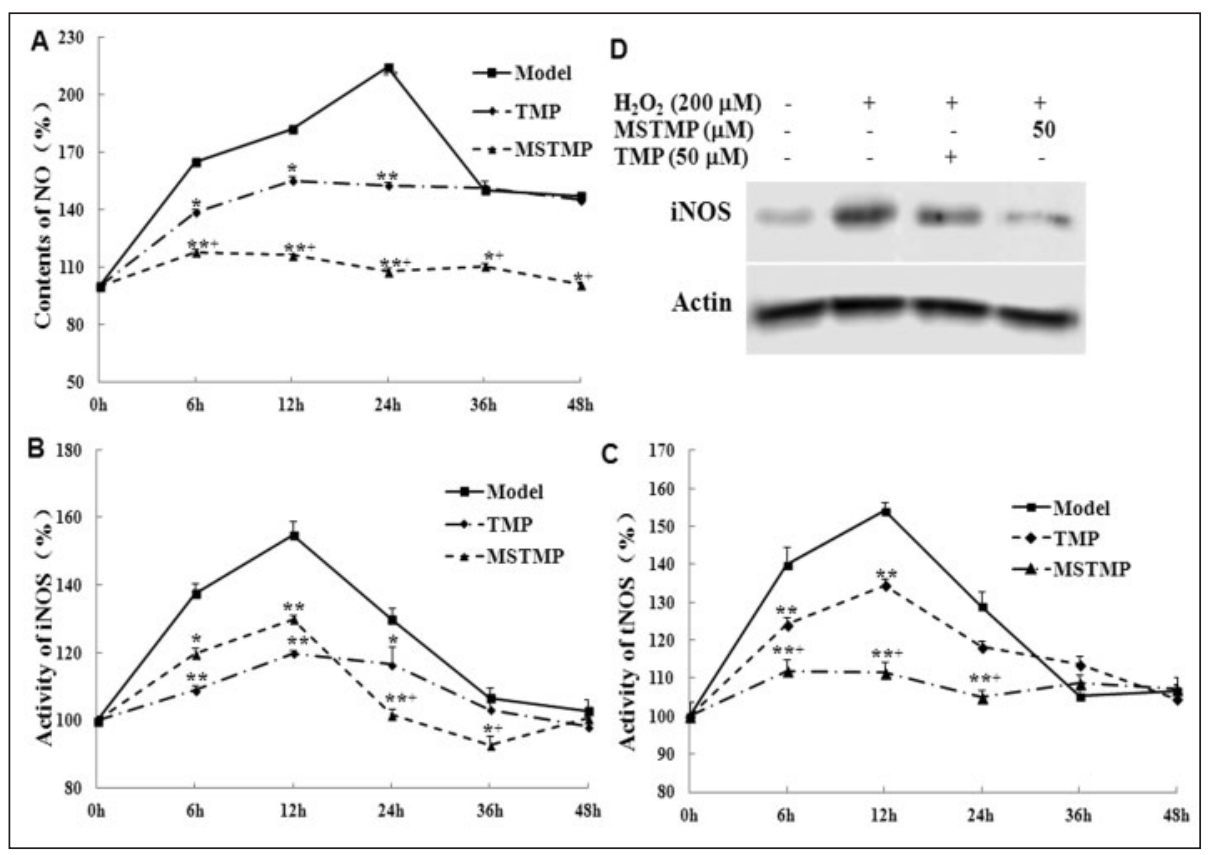

Figure 5: Effect of MSTMP on NO contents and $\mathrm{NOS}$ activity in $\mathrm{SH}-\mathrm{SY} 5 \mathrm{Y}$ cells injured by $\mathrm{H}_{2} \mathrm{O}_{2}$. SH-SY5Y cells were pretreated with $50 \mathrm{\mu mol} \cdot \mathrm{L}^{-1}$ MSTMP or TMP for $30 \mathrm{~min}$ and then exposed to $\mathrm{H}_{2} \mathrm{O}_{2}\left(200 \mu \mathrm{mol} \cdot \mathrm{L}^{-1}\right)$ for $12 \mathrm{~h}$. Cells were lysed and intracellular NO content, iNOS and tNOS activity were detected. The expression of iNOS was determined by western blotting. (A) NO contents; (B) iNOS activity; (C) tNOS activity. (D) iNOS expression. The data are expressed as mean $\pm S D .{ }^{* *} \mathrm{P}<0.01 \mathrm{vs} . \mathrm{H}_{2} \mathrm{O}_{2}$-stimulated cells (model); ${ }^{+} P<0.05,{ }^{++} P<0.01$ vs. cells treated with $\mathrm{H}_{2} \mathrm{O}_{2}+\mathrm{TMP}$. medication of TMP formulated to improve its pharmacodynamic and pharmacokinetic properties. In the present study, the cytoprotective effects of MSTMP against $\mathrm{H}_{2} \mathrm{O}_{2}$-induced oxidative stress in SH-SY5Y cells proved to be more potent than TMP at the same concentration.

Oxidative metabolites are involved in the functional inactivation of nerve cells due to increased permeability and, additionally, are potent inducers of neuron death. The intracellular MDA level reflects the extent of cell damage by oxidative stress. The endogenous antioxidant enzyme SOD and reductive compound $\mathrm{GSH}$ are thought to be crucial for augmentation of antioxidant defenses in cells. Superoxide dismutase can scavenge superoxide radicals by converting them to $\mathrm{H}_{2} \mathrm{O}_{2}$, which is then converted to water by catalase and glutathione peroxidase $(\mathrm{GSH}-\mathrm{Px})^{22}$. Our results showed that MSTMP reduced the reduction of the SOD activity and the GSH level and augmented MDA content in SH-SY5Y cells in response to $\mathrm{H}_{2} \mathrm{O}_{2}$. This suggests that the cytoprotective effect of MSTMP was likely related to the restoration of endogenous antioxidation and the decrease of lipid peroxidation.

Excessive production of ROS in cells can either directly or indirectly lead to mitochondrial dysfunction, apoptosis, and cell death $^{23}$. Reactive oxygen species can induce the release of apoptotic factors such as cytochrome $\mathrm{C}$ or apoptosis-inducing factor and then stimulate apoptotic-like biochemical caspases. Caspases are a family of cysteine proteases that cleave target proteins at specific residues. Among the more than ten members of the caspase family identified, caspase- 3 and caspase- 9 are major players in apoptosis induced by oxidative stress ${ }^{24,25}$. This study investigated the effects of MSTMP on the apoptosis rate and related protein expression. Results showed that the presence of MSTMP decreased intracellular ROS generation and reduced
SH-SY5Y cell apoptosis by inhibition of the expression of caspase-3 and caspase-9.

Some evidence has suggested that abnormal regulation of NO generation from neuronal nitric oxide synthase (nNOS) and iNOS is associated with many neuronal diseases, such as brain ischemia ${ }^{26}$, Parkinson's disease (PD) ${ }^{27}, \mathrm{AD}^{28}$, and amyotrophic lateral sclerosis ${ }^{29}$. Under normal conditions, the concentrations of NO in brain cells are very low. However, under pathological conditions, the production of ROS and NO increases and they combine with each other to form the reactant peroxynitrite $\left(\mathrm{ONOO}^{-}\right)^{30}$. Moreover, NOS could produce superoxide as well as NO in the presence of low arginine levels and that mtNOS could be an $\mathrm{ONOO}^{-}$synthase, thereby constituting an alternative source of $\mathrm{ONOO}^{-}$in vivo. Both $\mathrm{NO}$ and $\mathrm{ONOO}^{-}$can damage cellular components such as DNA and lipids by nitrosylation of proteins and inhibit mitochondrial respiratory chain enzymes and promote mitochondrial depolarization and cell death. In addition, it was reported that the treatment of NOS inhibitors could reverse the activation of the caspase cascade ${ }^{31}$. Therefore, ROS and NO possess very important roles in the apoptosis induced by oxidative stress. In this study, MSTMP significantly decreased the content of NO in SH-SY5Y cells by inhibiting iNOS expression and activity in a time-dependent manner. We also observed that the anti-apoptotic action and inactivation of caspase-3 of MSTMP are paralleled by a decrease in NO content. These results indicated that MSTMP inhibits SH-SY5Y cell apoptosis induced by $\mathrm{H}_{2} \mathrm{O}_{2}$ via a ROS-NO pathway. Furthermore, MSTMP shows a greater effect than TMP on inhibiting LDH release, scavenging ROS, apoptosis and NO production.

In the present study, we used SH-SY5Y cells to observe the neuroprotection of MSTMP against cellular oxidative stress. SH- 
SY5Y cells possess typical central nervous system (CNS) characteristics such as neurite-like cytoplasmic processes, the expression of neuronal specific tyrosine hydroxylase, cholinesterase, dopamine $\beta$ hydroxylase, etc ${ }^{32}$. Therefore, this cell line had wide use in the primary studies of drugs on neurodegenerative diseases, such as $\mathrm{AD}$ or $\mathrm{PD}^{33}$. We will further continue to investigate the neuroprotection of MSTMP on primary cultured neurons.

In conclusion, MSTMP significantly protected SH-SY5Y cells against $\mathrm{H}_{2} \mathrm{O}_{2}$ damage via anti-oxidative and anti-apoptosis effects. The antioxidant MSTMP diminishes the apoptosis of SH-SY5Y cells by inhibiting the activation of caspase- 3 and NO synthesis. These findings suggest that MSTMP may have important potential for the development of new agents for effective treatment of neurodegenerative diseases.

\section{ACKNOWLEDGEMENTS}

This work was funded by Shandong Province Outstanding Young Scientists Research Award Fund Project (BS2010SW020) and the National Science Foundation of China Grants (30973548).

\section{REFERENCES}

1. Cui K, Luo X, Xu K, Ven Murthy MR. Role of oxidative stress in neurodegeneration: recent developments in assay methods for oxidative stress and nutraceutical antioxidants. Prog Neuropsychopharmacol Biol Psychiatry. 2004;28:771-99.

2. Jeong $\mathrm{CH}$, Jeong HR, Choi GN, Kim DO, Lee U, Heo HJ. Neuroprotective and anti-oxidant effects of caffeic acid isolated from Erigeron annuus leaf. Chin Med. 2011;6:25-33.

3. Valencia A, Morán J. Reactive oxygen species induce different cell death mechanisms in cultured neurons. Free Radic Biol Med. 2004:36:1112-25.

4. Cardaci S, Filomeni G, Rotilio G, Ciriolo MR. p38(MAPK)/p53 signalling axis mediates neuronal apoptosis in response to tetrahydrobiopterin-induced oxidative stress and glucose uptake inhibition: implication for neurodegeneration. Biochem J. 2010; 430:439-51.

5. Zou YP, Lu YH, Wei DZ. Protective effects of a flavonoid-rich extract of Hypericum perforatum L. against hydrogen peroxideinduced apoptosis in PC12 cells. Phytother Res. 2010;24:S6-10.

6. Hintz KK, Ren J. Tetramethylpyrazine elicits disparate responses in cardiac contraction and intracellular $\mathrm{Ca}^{2+}$ transients in isolated adult rat ventricular myocytes. Vascul Pharmacol. 2003;40: 213-17.

7. Kao TK, Ou YC, Kuo JS, et al. Neuroprotection by tetramethylpyrazine against ischemiac brain injury in rats. Neurochem Int. 2006;48:166-76.

8. Ye Y, Wang S, Jiang J. Studies on the metabolites of tetramethylpyrazine in human urine. Zhongguo Yi Xue Ke Xue Yuan Xue Bao. 1996;18:288-91.

9. Xu R, Li Y, Huang X. Progresses of pharmacokinetic researches of tetrapyrazine. J Anhui TCM Coll. 2002;21:58-61.

10. Li F, Gong Q, Dong H, Shi J. Resveratrol, a neuroprotective supplement for Alzheimer's disease. Curr Pharm Des. 2012;18: 27-33.

11. Foti Cuzzola V, Ciurleo R, Giacoppo S, Marino S, Bramanti P. Role of resveratrol and its analogues in the treatment of neurodegenerative diseases: focus on recent discoveries. CNS Neurol Disord Drug Targets. 2011;10:849-62.

12. Petrovski G, Gurusamy N, Das DK. Resveratrol in cardiovascular health and disease. Ann N Y Acad Sci. 2011;1215:22-33.

13. Zhai L, Zhang P, Sun RY, Liu XY, Liu WG, Guo XL. Cytoprotective effects of CSTMP, a novel stilbene derivative, against $\mathrm{H}_{2} \mathrm{O}_{2}-$ induced oxidative stress in human endothelial cells. Pharmacol Rep. 2011;63:1469-80.
14. Hu XZ, Xu Y, Hu DC, Hui Y, Yang FX. Apoptosis induction on human hepatoma cells Hep G2 of decabrominated diphenyl ether (PBDE-209). Toxicol Lett. 2007;171:19-28.

15. Qian ZJ, Jung WK, Byun HG, Kim SK. Protective effect of an antioxidative peptide purified from gastrointestinal digests of oyster, Crassostrea gigas against free radical induced DNA damage. Bioresource Technol. 2008;99:3365-71.

16. Guo S, Bezard E, Zhao B. Protective effect of green tea polyphenols on the SH-SY5Y cells against 6-OHDA induced apoptosis through ROS-NO pathway. Free Radic Biol Med. 2005;39:682-95.

17. Yu J, Eto M, Kozaki K, Akishita M, Okabe T, Ouchi Y. Raloxifene analogue LY117018 suppresses oxidative stress-induced endothelial cell apoptosis through activation of ERK1/2 signaling pathway. Eur J Pharmacol. 2008;589:32-6.

18. Tsai FH, Lien JC, Lin LW, Chen HY, Ching H, Wu CR. Protective effect of Broussonetia papyrifera against hydrogen peroxideinduced oxidative stress in SH-SY5Y cells. Biosci Biotechnol Biochem. 2009; 73:1933-9.

19. Guizani N, Waly MI, Ali A, et al. Papaya epicarp extract protects against hydrogen peroxide-induced oxidative stress in human SH-SY5Y neuronal cells. Exp Biol Med. (Maywood) 2011;236: 1205-10.

20. Ding $Y$, Hou $X$, Chen $L$, et al. Protective action of tetramethylpyrazine on the medulla oblongata in rats with chronic hypoxia. Auton Neurosci. 2013;173:45-52.

21. Lv L, Jiang SS, Xu J, Gong JB, Cheng Y. Protective effect of ligustrazine against myocardial ischaemia reperfusion in rats: the role of endothelial nitric oxide synthase. Clin Exp Pharmacol Physiol. 2012;39:20-7.

22. Wang SW, Wang YJ, Su YJ, et al. Rutin inhibits $\beta$-amyloid aggregation and cytotoxicity, attenuates oxidative stress, and decreases the production of nitric oxide and proinflammatory cytokines. Neurotoxicology. 2012;33:482-90.

23. Sugawara T, Chan PH. Reactive oxygen radicals and pathogenesis of neuronal death after cerebral ischemia. Antioxid Redox Signal. 2003;5:597-607.

24. Choi BS, Sapkota K, Kim S, Lee HJ, Choi HS, Kim SJ . Antioxidant activity and protective effects of Tripterygium regelii extract on hydrogen peroxide-induced injury in human dopaminergic cells, SH-SY5Y. Neurochem Res. 2010;35:1269-80.

25. Sapkota K, Kim S, Park SE, Kim SJ. Detoxified extract of Rhus verniciflua stokes inhibits rotenone-induced apoptosis in human dopaminergic cells, SH-SY5Y. Cell Mol Neurobiol. 2011;31: 213-23.

26. Cui H, Lee JH, Kim JY, Koo BN, Lee JE. The neuroprotective effect of agmatine after focal cerebral ischemia in diabetic rats. J Neurosurg Anesthesiol. 2012;24:39-50.

27. Singh S, Kumar S, Dikshit M. Involvement of the mitochondrial apoptotic pathway and nitric oxide synthase in dopaminergic neuronal death induced by 6-hydroxydopamine and lipopolysaccharide. Redox Rep. 2010;15:115-22.

28. Colton CA, Vitek MP, Wink DA, et al. NO synthase 2 (NOS2) deletion promotes multiple pathologies in a mouse model of Alzheimer's disease. Proc Natl Acad Sci USA. 2006;103: 12867-72.

29. Martin LJ, Liu Z, Chen K, et al. Motor neuron degeneration in amyotrophic lateral sclerosis mutant superoxide dismutase-1 transgenic mice: mechanisms of mitochondriopathy and cell death. J Comp Neurol. 2007;500:20-46.

30. Kumar A, Singh RL, Babu GN. Cell death mechanisms in the early stages of acute glutamate neurotoxicity. Neurosci Res. 2010;66: 271-8.

31. Cellek S, Qu W, Schmidt AM, Moncada S. Synergistic action of advanced glycation end products and endogenous nitric oxide leads to neuronal apoptosis in vitro: a new insight into selective nitrergic neuropathy in diabetes. Diabetologia. 2004;47:331-9.

32. Jung Y, Lee $S$, Bang S, et al. TRF2 is in neuroglial cytoplasm and induces neurite-like processes. FEBS Lett. 2004;557:129-32.

33. Sánchez S, Jiménez C, Carrera AC, Diaz-Nido J, Avila J, Wandosell F. A cAMP-activated pathway, including PKA and PI3K, regulates neuronal differentiation. Neurochem Int. 2004;44: $231-42$ 